\title{
Microstructure Transformation In Palm-Fiber Cell Wall And Its Influence On the Fiber's Mechanical Properties During Alkali Treatment
}

Lingxiao Jing ( $\sim 343745223 @ q q . c o m$ )

College of Sericulture, Textiles and Biomass Sciences, Southwest University,Chongqing,China https://orcid.org/0000-0001-6940-4634

Ying Jiang

College of Sericulture, Textiles and Biomass Sciences,Southwest University

Penghu Deng

Southwest University

Yuehan Wang

Southwest University

Yifa Ma

Honghe Palm Industry Associaton

Tonghua Zhang

College of Sericulture, Textiles and Biomass Sciences https://orcid.org/0000-0002-1921-4135

\section{Research Article}

Keywords: Palm fiber, Alkali treatment, Imaging technology, Tensile properties, Microstructure transformation

Posted Date: December 22nd, 2021

DOI: https://doi.org/10.21203/rs.3.rs-1138321/v1

License: (a) (1) This work is licensed under a Creative Commons Attribution 4.0 International License. Read Full License 


\section{Abstract}

In this study, we examined the microstructure transformation of palm fiber and the influence of this transformation on the fiber mechanical properties during alkali treatment. The fibers were treated with different concentrations of $\mathrm{NaOH}$ to study the change rules of the microstructure and the tensile properties. FT-IR microspectroscopic imaging and confocal laser scanning microscopy were adopted to observe microstructure transformation during alkali treatment. Research results showed that the hemicellulose and lignin in the fiber cell wall were removed by alkali treatment, leading to a rearrangement of cellulose chains. The tensile properties palm fibers were significantly improved because of crystallinity alterations in the cell walls after alkali treatment. This study might provide a basis for palm fiber's high-value utilization in the field of materials.

\section{Introduction}

Palm leaf sheath fiber (palm fiber), a kind of natural multicellular plant fiber, is widely used in households, civil construction, water conservation, and environmental engineering because of its excellent performance and high utilization value (Zhang et al. 2015; Chowdhury et al. 2013; Moshiul et al. 2012). Generally, plant cell walls consist of complex polymers such as cellulose, hemicellulose, and lignin, which are linked to one another by noncovalent and covalent bonds to form complex structures and chemical networks (Chabbert et al. 2018; Fincher et al. 2010). Cellulose is arranged regularly as the skeleton structure of the cell wall, which is composed of crystalline and amorphous regions (Kathirselvam et al. 2019; Djafari 2017). Lignin is a complex present in the cell walls of vascular plants. Hemicellulose and lignin are cross-linked by ester and ether bonds and are filled in microfibrils to act as a binder (Sant'Anna et al. 2013). Changes in polymer components can inevitably affect the microstructure of the cell wall, leading to changes in mechanical properties.

To prepare natural-fiber-reinforced composites, chemical treatment is often used to modify the fiber's structure and tensile properties (Dhakal et al. 2018). Khanam (2007) and Borchani (2015) found that alkali treatment improved the tensile, flexural, and compressive strengths of sisal/silk hybrid composites. Boopathi (2012) and Reddy (2013) chemically modified borassus fruit fibers and found that alkali treatment significantly improves the tensile properties of fibers compared with untreated ones. Moreover, impurities existing on the fiber surface and hemicellulose can be removed when alkalized (Alawar et al. 2009; Das and Chakraborty 2008; Rout et al. 2001). The mechanical properties of fiber are believed to rely on the molecular architecture of its cell wall (Lee et al. 2011). The distribution of cellulose, hemicellulose, and lignin, the way of bonding, and the properties among the cell-wall components importantly affect the architecture and mechanical properties of fiber. Thus, alkali treatment plays a key role in changing the components of the fiber cell wall, leading to microstructure transformation of the fiber. In recent years, modern imaging technology has been used widely in biomaterial analysis. FT-IR microscopy has been proven to be a powerful method for revealing the chemical structure and components distribution of plant tissues at the cellular level with high spatial resolution (Cao et al. 2014; Ding et al. 2016; Guo et al. 2015). Confocal laser scanning microscopy (CLSM) is used to investigate lignin distribution in cell walls through 
lignin production of autofluorescence under specific excitation and emission wavelengths ( $\mathrm{Ji}$ et al. 2015; Marin-Bustamante et al. 2018). However, few studies have dealt with the components and microstructure changes of plant-fiber cell wall after chemical treatment by using imaging technology. The relationship between microstructure and mechanical properties during alkali treatment is also rarely reported.

Accordingly, imaging technologies may effectively determine how alkali treatment affects the components and microstructure of fiber.

In the present work, palm fibers were treated by alkali with different concentrations $(2,5$, and $10 \mathrm{wt} . \%)$, and the tensile properties of the fibers were tested. Imaging FT-IR microspectroscopy and CLSM were adopted to investigate the changes in components and microstructure in the fiber cell wall. Quantitative analyses on the component changes were performed to verify the imaging results. The mechanism of the effect of alkali treatment on fiber mechanical properties was explored.

\section{Materials And Methods \\ 2.1 Materials}

Palm fibers were obtained in Yunnan province, China. The fibers were washed in water to remove dust and impurities and then dried in an oven at $60^{\circ} \mathrm{C}$ for $24 \mathrm{~h}$. The dry palm fibers were treated with 2,5 , and $10 \mathrm{wt} . \% \mathrm{NaOH}$ solution separately for about $2 \mathrm{~h}$ at room temperature. The treated fibers were washed with fresh water to remove residual $\mathrm{NaOH}$ and then dried at room temperature for $24 \mathrm{~h}$. By using a sliding microtome, $10 \mu \mathrm{m}$-thick polyethylene glycol (PEG) embedded-fiber transverse-section slides were prepared for imaging FT-IR microscopy and confocal laser fluorescent microscopy analysis. Fig. 1 shows the preparation for palm fibers analysis. For comparative analysis, untreated palm fibers (raw) were also subjected to the experiments.

\subsection{Tensile properties}

Tensile testing of palm fibers was carried out with a Universal Testing Machine (gauge length, $20 \mathrm{~mm}$ ) at a rate of $2 \mathrm{~mm} / \mathrm{min}$. Thirty specimens for each group were subjected to tensile tests, and the average values were noted. The average diameter of palm fiber was determined by measuring three points in the tensile zone. Strain-stress curves of each group were graphed with Origin software.

\subsection{FT-IR microspectroscopic imaging}

The embedded-fiber transverse-section slides were placed in a warm water bath to expand PEG and then transferred onto ZnS slides. After drying at $50^{\circ} \mathrm{C}$, PEG was removed by placing the slides in $100 \%$ (two times), $80 \%, 50 \%$, and $25 \%$ ethanol-water solution for 10 min. Finally, the slides were washed three times with distilled water to remove ethanol and then freeze dried for FT-IR microspectroscopic imaging analysis. The FT-IR microspectroscopic images were recorded on a Spectrum Spotlight 400 FT-IR microscope (PerkinElmer Inc., Shelton, CT, USA). The spectra were recorded with a $4 \mathrm{~cm}-1$ spectral resolution, between $4000 \mathrm{~cm}-1$ and $740 \mathrm{~cm}-1$. 


\subsection{CLSM}

The transverse-section slides were rinsed with deionized water in a watch glass 10 times to remove PEG. After dehydration through a graded series of ethanol solution $(50 \%, 70 \%, 90 \%$, and $100 \%)$, the slides were mounted in glycerol, covered with a coverslip, and examined with an LSM 510 META laser confocal scanning microscope. The excitation wavelength was $488 \mathrm{~nm}$ and the emission wavelength at $568 \mathrm{~nm}$ for imaging lignin autofluorescence analysis.

\subsection{Chemical-component quantitative analysis}

Chemical analysis of the palm fibers was carried out according to the Method of Quantitative Analysis of Ramie Chemical Components (GB5889-86). The content changes of the cellulose, hemicellulose, and lignin before and after alkali treatment were accurately determined.

\section{Results And Discussion}

\subsection{Tensile properties}

\subsubsection{Fiber-diameter distribution}

Table 1 lists the average diameters of raw, 2, 5, and $10 \mathrm{wt} . \%$ alkali-treated palm fibers. It is shown that alkali treatment contributed to decreased fiber diameter with increased alkali concentration. In fact, impurities on the fiber surface and some components were removed during alkali treatment (Boopathi et al. 2012, Kathirselvam et al. 2019). The fiber structure was only slightly affected, resulting in more fibrillation and giving rise to finer fibers.

Table 1

Diameters of raw and alkali-treated palm fiber.

\begin{tabular}{|lccl|}
\hline Samples & Maximum diameter $(\mathrm{mm})$ & Minimum diameter $(\mathrm{mm})$ & Average diameter $(\mathrm{mm})$ \\
\hline Raw & 0.47 & 0.41 & $0.44 \pm 0.03$ \\
\hline 2 wt.\% & 0.46 & 0.37 & $0.41 \pm 0.03$ \\
\hline 5 wt.\% & 0.43 & 0.35 & $0.39 \pm 0.03$ \\
\hline 10 wt.\% & 0.41 & 0.34 & $0.36 \pm 0.04$ \\
\hline \multicolumn{4}{l}{ Mean \pm standard deviation based on 30 data. } \\
\hline
\end{tabular}

\subsubsection{Tensile properties of palm fiber}


Table 2

Tensile properties of raw and alkali-treated palm fibers.

\begin{tabular}{|llll|}
\hline Samples & Tensile strength (MPa) & Elongation (\%) & Young's modulus (MPa) \\
\hline Raw & $173.2 \pm 12.4$ & $37.97 \pm 1.3$ & $3032.2 \pm 266$ \\
\hline 2 wt.\% & $208.7 \pm 12.8$ & $40.58 \pm 1.6$ & $3880.3 \pm 301$ \\
\hline 5 wt.\% & $230 \pm 12.3$ & $44.1 \pm 1.7$ & $3718.9 \pm 368$ \\
\hline 10 wt.\% & $191.3 \pm 15.5$ & $33.57 \pm 1.7$ & $4192.9 \pm 323$ \\
\hline Mean \pm standard deviation based on 30 data. & \\
\hline
\end{tabular}

The test results of tensile strength, elongation, and Young's modulus of alkali-treated (2, 5, and $10 \mathrm{wt} . \%$ $\mathrm{NaOH}$ ) and raw fibers are shown in Table 2. Typical palm fiber stress-strain curves are plotted in Fig. 2. The tensile strength, elongation, and Young's modulus obviously increased within the alkali concentration range of $0-5 \mathrm{wt} . \%$. When the alkali concentration reached $10 \mathrm{wt} . \%$, Young's modulus was greatly improved whereas tensile strength and elongation decreased. Alkali treatment removed hydrogen bonds in cellulose and lignin cross-linked networks, resulting in large elongation (Cai et al. 2015; Ishikura et al. 2009; Rahman and Khan 2007). Fiber-microstructure transformations, such as changes microfibril angle and cellulose crystallinity, as well as the breakage of alkali-sensitive bonds between cellulose and hemicellulose, are attributed to the increased tensile strength and Young's modulus. Due to the large-scale removal of hemicellulose by alkali treatment and the formation of new hydrogen bonds among the chains of cellulose fibrils, the fibers were rearranged in a more compact manner, thereby increasing the tight packing of the fibers (Wang et al. 2003; Cai et al. 2015). Consequently, the elongation and tensile strength decreased and the Young's modulus increased with excess alkali treatment.

\subsection{Microstructure imaging \\ 3.2.1 Palm fiber cell wall FT-IR imaging}

FT-IR microspectroscopic data can be displayed as chemical images of specific wavelengths. Red and pink regions corresponded to larger absorption intensity, whereas blue regions corresponded to smaller absorption intensity. The chemical images at peaks near $1240 \mathrm{~cm}^{-1}$ showed the relative concentrations and distribution of cellulose. The area under the peak at $1508 \mathrm{~cm}^{-1}$ indicated the concentration and distribution of lignin. The concentrations and distribution of hemicelluloses were found at bands near $1710 \mathrm{~cm}^{-1}$ (Dokken et al. 2007, Cao et al., 2014). Fig. 3 shows the relative concentration and distribution of cellulose, lignin, and hemicellulose of raw and alkali-treated palm fiber transverse sections. As shown in Fig. 3(a), with increased alkali concentration, the red region decreased slightly, indicating that the cellulose content decreased. Figs. 3(b) and 3(c) show a significant decrease in red whereas the blue regions increased with increased alkali concentration, indicating that the lignin and hemicellulose contents dropped evidently. The spatial transformation of lignin and hemicellulose distribution and concentration indicated that their contents decreased during alkali treatment. 
The FT-IR spectra of raw and alkali-treated palm fibers were analyzed to investigate the effect of alkali treatment on the chemical characteristics of fiber cell wall. Fig. 4 shows the FT-IR spectra of the cell wall in the fingerprint region $\left(1800 \mathrm{~cm}^{-1}\right.$ to $\left.800 \mathrm{~cm}^{-1}\right)$. Specific spectral signals assigned to absorption bands of cellulose, hemicelluloses, and lignin were examined. Typical bands assigned to cellulose were located at 1424 and $1368 \mathrm{~cm}^{-1}$ for $\mathrm{CH}_{2}$ scissor motion and $\mathrm{C}-\mathrm{H}$ bending vibrations, respectively, at $1336 \mathrm{~cm}^{-1}$ for $\mathrm{OH}$ in-plane bending of amorphous cellulose, and at $1316 \mathrm{~cm}^{-1}$ for $\mathrm{CH}_{2}$ wagging vibrations in crystalline cellulose (Guo et al. 2015; Huang et al. 2013; Lionetto et al. 2012; Yin et al. 2011), which can be used to assess structural changes in cellulose. According to Huang and Lionetto (Colom et al. 2003; Huang et al. $2013)$, the absorbance ratio $\left(I_{1316} / I_{1336}\right)$ provides additional information on the difference in the degradation process of amorphous and crystalline cellulose, wherein an increase in the ratio indicates increased crystallinity. For raw and alkali-treated palm fibers, this ratio were 1.06, 1.08, 1.1, and 1.09, respectively. Based on the results, we concluded that alkali treatment increased the crystalized-cellulose content, which helped improve the tensile properties. For hemicelluloses, the characteristic peaks at 1740 and $1710 \mathrm{~cm}^{-1}$ were assigned to the $\mathrm{C}=0$ stretching vibration in the $\mathrm{O}=\mathrm{C}-\mathrm{O}$ group of the glucuronic acid unit in xylan (Akerholm and Salmen 2003; Song et al. 2013; Stevanic and Salme 2009). As for lignin, the characteristic peaks at $1600 \mathrm{~cm}^{-1}$ can be ascribed to the aromatic skeletal vibrations together with $\mathrm{C}=0$ stretching, and those at $1508 \mathrm{~cm}^{-1}$ can be ascribed to the aromatic skeletal vibration and guaiacyl ring vibration. The xylan band at $1456 \mathrm{~cm}^{-1}$ can be ascribed to $\mathrm{CH}_{2}$ symmetric bending on the xylose ring, whereas that at $1264 \mathrm{~cm}^{-1}$ can be ascribed to $C=0$ stretching (Shi et al. 2012; Song et al. 2013).

The relative intensities of the absorption peaks at 1740, 1710, 1600, and $1508 \mathrm{~cm}^{-1}$ in palm as a function of treatments are shown in Fig .5. The density at $1740 \mathrm{~cm}^{-1}$ decreased by $24 \%$ for treatment at $2 \mathrm{wt} . \%$ $\mathrm{NaOH}, 63.5 \%$ for treatment at $5 \mathrm{wt} . \% \mathrm{NaOH}$, and $65 \%$ for treatment at $10 \mathrm{wt} . \% \mathrm{NaOH}$. The density at 1710 $\mathrm{cm}^{-1}$ decreased by $3.2 \%$ for treatment at $2 \mathrm{wt} . \% \mathrm{NaOH}, 33.3 \%$ for treatment at $5 \mathrm{wt} . \% \mathrm{NaOH}$, and $38.7 \%$ for treatment at $10 \mathrm{wt} . \% \mathrm{NaOH}$. This significant loss in absorption of the carbonyl group, which comprised the backbone of xylan, at higher alkali concentrations most likely resulted from the degradation and loss of hemicelluloses from the cell wall. A similar observation was reported by Reddy $(2009,2012)$. The lignin-band intensity at $1600 \mathrm{~cm}^{-1}$ showed a slight increase by $4.6 \%$ for treatment at 2 wt.\% $\mathrm{NaOH}$, a decrease by $14.7 \%$ for treatment at $5 \mathrm{wt} . \% \mathrm{NaOH}$, and a decrease by $18.9 \%$ for treatment at $10 \mathrm{wt} . \% \mathrm{NaOH}$. For the aromatic skeletal vibration band at $1508 \mathrm{~cm}^{-1}$, relative intensities increased by $2.7 \%$ for treatment at $2 \mathrm{wt} . \% \mathrm{NaOH}, 13.4 \%$ for treatment at $5 \mathrm{wt} . \% \mathrm{NaOH}$, and $14 \%$ for treatment at 10 wt.\% $\mathrm{NaOH}$. A loss of the $\mathrm{C}=\mathrm{O}$ group linked to the aromatic skeleton may have probably occurred. This finding indicated the occurrence of cross-linking among the aromatic units in the lignin probably caused by the alkali treatment (Yin et al. 2011).

We observed that the bands at 1600 and $1508 \mathrm{~cm}^{-1}$, which were assigned to lignin, increased slightly upon $2 \mathrm{wt}$ \% $\mathrm{NaOH}$ treatment (Fig. 5). This result indicated that the significant degradation of hemicelluloses subsequently caused a slightly increase in the lignin component of cell wall. A similar observation has been made by Huang (Huang et al. 2013). The removal of hemicelluloses and lignin in 
cell walls may have likely enhanced the exposure of cellulose microfibrils, consequently increasing the tensile properties of the fibers.

\subsubsection{CLSM imaging of palm lignin autofluorescence}

To further study lignin's microstructure transformation and distribution characteristics in palm fiber cell wall, CLSM was used to investigate the lignin distribution and relative lignin concentration. Lignin concentration is linearly proportional to image brightness, which can be evaluated by image brightness (Ding et al. 2016). Fluorescence in cell walls originated from lignin autofluorescence, which comprised monolignols. Fig. 6 shows the autofluorescence images of raw and alkali-treated samples at different concentrations. Figs. 6(a, e) demonstrate the heterogeneous distribution of lignin in raw fibers, with higher lignin autofluorescence intensity occurring in the cell corner middle lamella and compound middle lamella regions. For the sample treated by $2 \mathrm{wt}$ \% $\mathrm{NaOH}$, fluorescence intensity in cell wall increased probably due to the aggregation-induced emission effect of lignin. Furthermore, a continuous increase in $\mathrm{NaOH}$ concentration to 10 wt.\% caused an obvious decrease in fluorescence intensity, which may be attributed to a significant degradation of hemicelluloses linked to lignin by ester and ether bonds. Overall, the transformation of fluorescence reflected changes in lignin component and organization in addition to changes in interactions with other polymers, particularly with hemicelluloses (Chabbert et al. 2018). This conclusion was consistent with the FT-IR microspectroscopic analysis.

\subsection{Chemical components of palm fiber}

Table 3

Chemical composition of raw and alkali-treated palm fibers.

\begin{tabular}{|lllll|}
\hline Samples & Hemicellulose (\%) & Lignin (\%) & Cellulose (\%) & Impurities (\%) \\
\hline Raw & 23.5 & 38.18 & 28.04 & 10.28 \\
\hline 2 wt.\% & 17.25 & 36.18 & 38.43 & 8.14 \\
\hline 5 wt.\% & 13.2 & 34.1 & 45.57 & 7.13 \\
\hline 10 wt.\% & 10.82 & 28.66 & 55.16 & 5.36 \\
\hline
\end{tabular}

The chemical components of raw and alkali-treated fibers are presented in Table 3. Raw fiber consisted of cellulose (28.04\%), hemicelluloses (23.5\%), lignin (38.18\%), and impurities (10.28\%). Hemicellulose was significantly affected by the concentration of the alkaline solution, which decreased from 23.5-10.82\%. Lignin content decreased from 38.18-28.66\%, and the impurity content decreased from 10.28-5.36\%. Correspondingly, cellulose content increased from $28.04-55.16 \%$. These results were consistent with those of FT-IR microspectroscopy and CLSM analyses.

\section{Conclusion}

The microstructure transformation of alkali-treated palm fiber and the influence of this transformation on fiber mechanical properties were studied in this paper. Results showed that the tensile properties of palm fibers increased after alkali treatment because of the microstructure transformation. FT-IR 
microspectroscopy and CLSM analyses provided new information on cell-wall microstructure transformation resulting from the removal of hemicelluloses and lignin. The fibrils rearranged themselves in a compact manner that resulted in a close packing of cellulose chains, which may have led to the increased tensile properties. These findings may benefit the high-value utilization of palm in the field of materials.

\section{References}

1. Akerholm M, Salmen L (2003) The oriented structure of lignin and its viscoelastic properties studied by static and dynamic FT-IR spectroscopy, Holzforschung. 57:459-465. https://doi.org/10.1515/HF.2003.069

2. Alawar A, Hamed AM, Al-Kaabi K (2009) Characterization of treated date palm tree fiber as composite reinforcement. Composites Part B, Engineering 40:601-606.

.https://doi.org/10.1016/j.compositesb.2009.04.018

3. Boopathi L, Sampath PS, Mylsamy K (2012) Investigation of physical, chemical and mechanical properties of raw and alkali treated Borassus fruit fiber. Composites Part B, Engineering 43:30443052. https://doi.org/10.1016/j.compositesb.2012.05.002

4. Borchani K, Elfehri C, Carrot, Jaziri M (2015) Untreated and alkali treated fibers from Alfa stem: effect of alkali treatment on structural, morphological and thermal features. Cellulose (London) 22:15771589. .https://doi.org/10.1007/s10570-015-0583-5

5. Cai M, Takagi H, Nakagaito AN, Katoh M, Ueki T, Waterhouse GIN, Li Y (2015) Influence of alkali treatment on internal microstructure and tensile properties of abaca fibers. Ind Crops Prod 65:27-35. .https://doi.org/10.1016/j.indcrop.2014.11.048

6. Cao C, Yang Z, Han L, Jiang X, Ji G (2014) Study on in situ analysis of cellulose, hemicelluloses and lignin distribution linked to tissue structure of crop stalk internodal transverse section based on FTIR microspectroscopic imaging, Cellulose (London. 22:139-149. .https://doi.org/10.1007/s10570-0140525-7

7. Chabbert B, Terryn C, Herbaut M, Vaidya A, Habrant A, Paës G, Donaldson L (2018) Fluorescence techniques can reveal cell wall organization and predict saccharification in pretreated wood biomass. Ind Crops Prod 123:84-92. .https://doi.org/10.1016/j.indcrop.2018.06.058

8. Chowdhury MNK, Beg MDH, Khan MR, Mina MF (2013) Modification of oil palm empty fruit bunch fibers by nanoparticle impregnation and alkali treatment. Cellulose (London) 20:1477-1490. .https://doi.org/10.1007/s10570-013-9921-7

9. Colom X, Carrillo F, Nogués F, Garriga P (2003) Structural analysis of photodegraded wood by means of FTIR spectroscopy. Polym Degrad Stab 80:543-549. .https://doi.org/10.1016/S01413910(03)00051-X

10. Das M, Chakraborty D (2008) Evaluation of improvement of physical and mechanical properties of bamboo fibers due to alkali treatment. J Appl Polym Sci 107:522-527.

https://doi.org/10.1002/app.26155 
11. Dhakal H, Bourmaud A, Berzin F, Almansour F, Zhang Z, Darshil U, Shah, Beaugrand J (2018) Mechanical properties of leaf sheath date palm fibre waste biomass reinforced polycaprolactone (PCL) biocomposites, Industrial crops and products. 126:394-402. .https://doi.org/10.1016/j.indcrop.2018.10.044

12. Ding D, Zhou X, Ji Z, Xu F (2016) How Does Hemicelluloses Removal Alter Plant Cell Wall Nanoscale Architecture and Correlate with Enzymatic Digestibility?, Bioenergy research. 9:601-609. https://doi.org/10.1007/s12155-015-9703-1

13. Djafari Petroudy SR (2017) '3 - Physical and mechanical properties of natural fibers.' in Mizi Fan and Feng Fu (eds.), Advanced High Strength Natural Fibre Composites in Construction (Woodhead Publishing)

14. Dokken KM, Davis LC, Source Brookhaven National Laboratory National Synchrotron Light (2007) Infrared Imaging of Sunflower and Maize Root Anatomy. J Agric Food Chem 55:10517-10530. https://doi.org/10.1021/jf072052e

15. Fincher GB, Rachel A, Burton, Gidley MJ (2010) Heterogeneity in the chemistry, structure and function of plant cell walls. Nat Chem Biol 6:724-732. https://doi.org/10.1038/nchembio.439

16. Guo J, Song K, Salmén L, Yin Y (2015) Changes of wood cell walls in response to hygro-mechanical steam treatment. Carbohydr Polym 115:207-214. .https://doi.org/10.1016/j.carbpol.2014.08.040

17. Guo J, Zhou H, Stevanic JS, Dong M, Yu M, Salmén L, Yin Y (2017) Effects of ageing on the cell wall and its hygroscopicity of wood in ancient timber construction. Wood Sci Technol 52:131-147. .https://doi.org/10.1007/s00226-017-0956-z

18. Huang X, Kocaefe D, Kocaefe Y, Boluk Y, Cornélia Krause (2013) Structural analysis of heat-treated birch (Betule papyrifera) surface during artificial weathering. Appl Surf Sci 264:117-127. https://doi.org/10.1016/j.apsusc.2012.09.137

19. Ishikura Y, Abe K, Hiroyuki Yano (2009) Bending properties and cell wall structure of alkali-treated wood. Cellulose (London) 17:47-55. https://doi.org/10.1007/s10570-009-9360-7

20. Ji Z, Zhang X, Ling Z, Zhou X, Ramaswamy S, Xu F (2015) Visualization of Miscanthus $\times$ giganteus cell wall deconstruction subjected to dilute acid pretreatment for enhanced enzymatic digestibility. Biotechnol Biofuels 8:103-103. .https://doi.org/10.1186/s13068-015-0282-3

21. Kathirselvam M, Kumaravel A, Arthanarieswaran VP, Saravanakumar SS (2019) Characterization of cellulose fibers in Thespesia populnea barks: Influence of alkali treatment. Carbohydr Polym 217:178-189. .https://doi.org/10.1016/j.carbpol.2019.04.063

22. Khanam P, Noorunnisa M, Mohan Reddy K, Raghu K, John, Venkata Naidu S (2007) Tensile, flexural and Compressive properties of sisal/silk hybrid composites. J Reinf Plast Compos 26:1065-1070. https://doi.org/10.1177/0731684407079347

23. Labbé N, Rials TG, Kelley SS, Cheng Z-M, Kim J-Y, Li Y (2005) FT-IR imaging and pyrolysis-molecular beam mass spectrometry: new tools to investigate wood tissues. Wood Sci Technol 39:61-76. .https://doi.org/10.1007/s00226-004-0274-0 
24. Lee KJD, Susan E, Marcus, Paul Knox J (2011) Cell Wall Biology: Perspectives from Cell Wall Imaging, Molecular plant, 4: 212-19.https://doi.org/10.1093/mp/ssq075

25. Lionetto F, Sole RD, Cannoletta D, Vasapollo G (2012) Monitoring Wood Degradation during Weathering by Cellulose Crystallinity, Materials. 5:1910-1922. .https://doi.org/10.3390/ma5101910. Alfonso Maffezzoli

26. Marin-Bustamante MQ, Chanona-Pérez JJ, Guemes-Vera N, Arzate-Vázquez I, Perea-Flores MJ, Mendoza-Pérez JA, Calderón-Domínguez G, Casarez-Santiago RG (2018) Evaluation of physical, chemical, microstructural and micromechanical properties of nopal spines (Opuntia ficus-indica), Industrial crops and products. 123:707-718. https://doi.org/10.1016/j.indcrop.2018.07.030

27. McCann MC, Chen L, Roberts K, Kemsley EK, Sene C, Carpita NC, Stacey NJ, Wilson RH (1997) Infrared microspectroscopy: Sampling heterogeneity in plant cell wall composition and architecture. Physiol Plant 100:729-738. .https://doi.org/10.1034/j.1399-3054.1997.1000337.x

28. Moshiul Alam AKM, Beg MDH, Reddy Prasad DM, Khan MR, Mina MF (2012) Structures and performances of simultaneous ultrasound and alkali treated oil palm empty fruit bunch fiber reinforced poly(lactic acid) composites, Composites. Part A, Applied science and manufacturing. 43:1921-1929. https://doi.org/10.1016/j.compositesa.2012.06.012

29. Obi Reddy K, Shukla M, Uma Maheswari C, Varada Rajulu A (2012) Mechanical and physical characterization of sodium hydroxide treated Borassus fruit fibers. Journal of forestry research 23:667-674. https://doi.org/10.1007/s11676-012-0308-7

30. Obi Reddy K, Maheswari CU, Shukla M, Song Jl, Varada Rajulu A (2013) Tensile and structural characterization of alkali treated Borassus fruit fine fibers. Composites Part B, Engineering 44:433438. .https://doi.org/10.1016/j.compositesb.2012.04.075

31. Rahman M, Mizanur, Khan MA (2007) Surface treatment of coir (Cocos nucifera) fibers and its influence on the fibers' physico-mechanical properties. Compos Sci Technol 67:2369-2376. .https://doi.org/10.1016/j.compscitech.2007.01.009

32. Reddy K, Obi BR, Guduri, Varada Rajulu A (2009) Structural characterization and tensile properties of Borassus fruit fibers. J Appl Polym Sci 114:603-611. https://doi.org/10.1002/app.30584

33. Sant'Anna, Celso LT, Costa Y, Abud L, Biancatto FC, Miguens (2013) Sugarcane cell wall structure and lignin distribution investigated by confocal and electron microscopy, Microscopy research and technique. 76:829-834. .https://doi.org/10.1002/jemt.22235. Wanderley de Souza

34. Shi J, Xing D, Lia J (2012) FTIR Studies of the Changes in Wood Chemistry from Wood Forming Tissue under Inclined Treatment, Energy procedia. 16:758-762.

.https://doi.org/10.1016/j.egypro.2012.01.122

35. Song K, Yin Y, Salmén L, Jiang X (2013) Changes in the properties of wood cell walls during the transformation from sapwood to heartwood. J Mater Sci 49:1734-1742.

.https://doi.org/10.1007/s10853-013-7860-1

36. Stevanic JS, Lennart Salme (2009) Orientation of the wood polymers in the cell wall of spruce wood fibres. Holzforschung 63:497-503. .https:// doi.org/10.1515/HF.2009.094

Page 10/16 
37. Wang Y-S, Koo W-M, Han-Do Kim (2003) Preparation and Properties of New Regenerated Cellulose Fibers. Text Res J 73:998-1004. https://doi.org/10.1177/004051750307301110

38. Yin Y, Berglund L (2011) Effect of Steam Treatment on the Properties of Wood Cell Walls, Biomacromolecules. 12:194-202. https://doi.org/10.1021/bm101144m. Lennart Salmén

39. Zhang T, Guo M, Cheng L, Li X (2015) Investigations on the structure and properties of palm leaf sheath fiber. Cellulose (London) 22:1039-1051. .https://doi.org/10.1007/s10570-015-0570-x

40. Zhang, Tonghua, Min Guo, Lan Cheng, and Xiaolong Li. (2015). Investigations on the structure and properties of palm leaf sheath fiber, Cellulose (London), 22: 1039-

51.https://doi.org/10.1007/s10570-015-0570-x

\section{Figures}

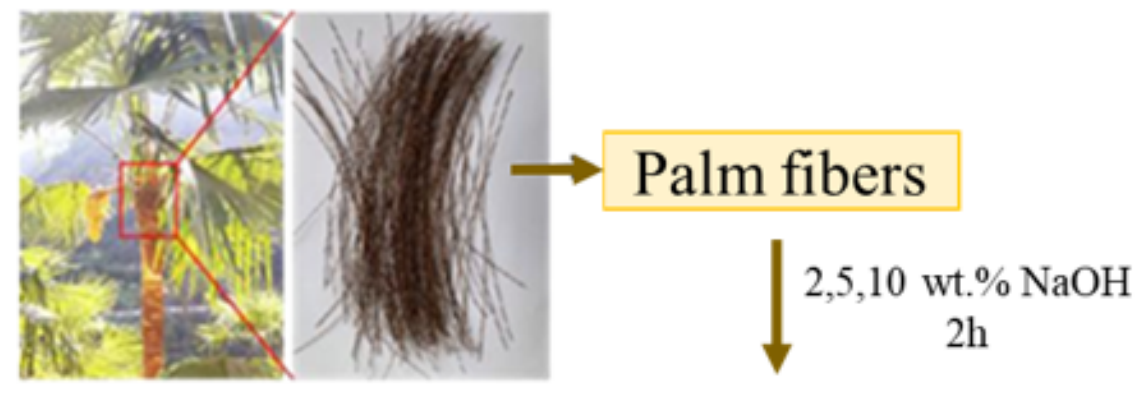

\section{Alkali treated palm fibers}

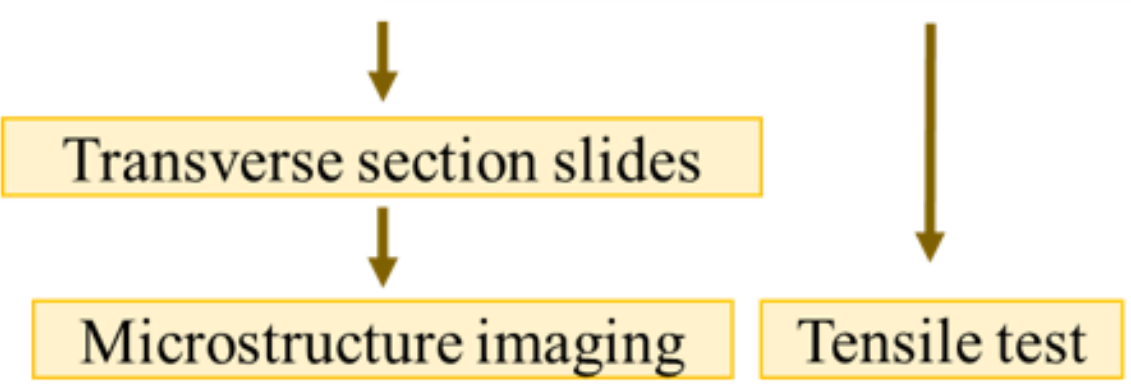

Chemical components quantitative analysis

\section{Figure 1}

The preparation process for palm fibers analysis 


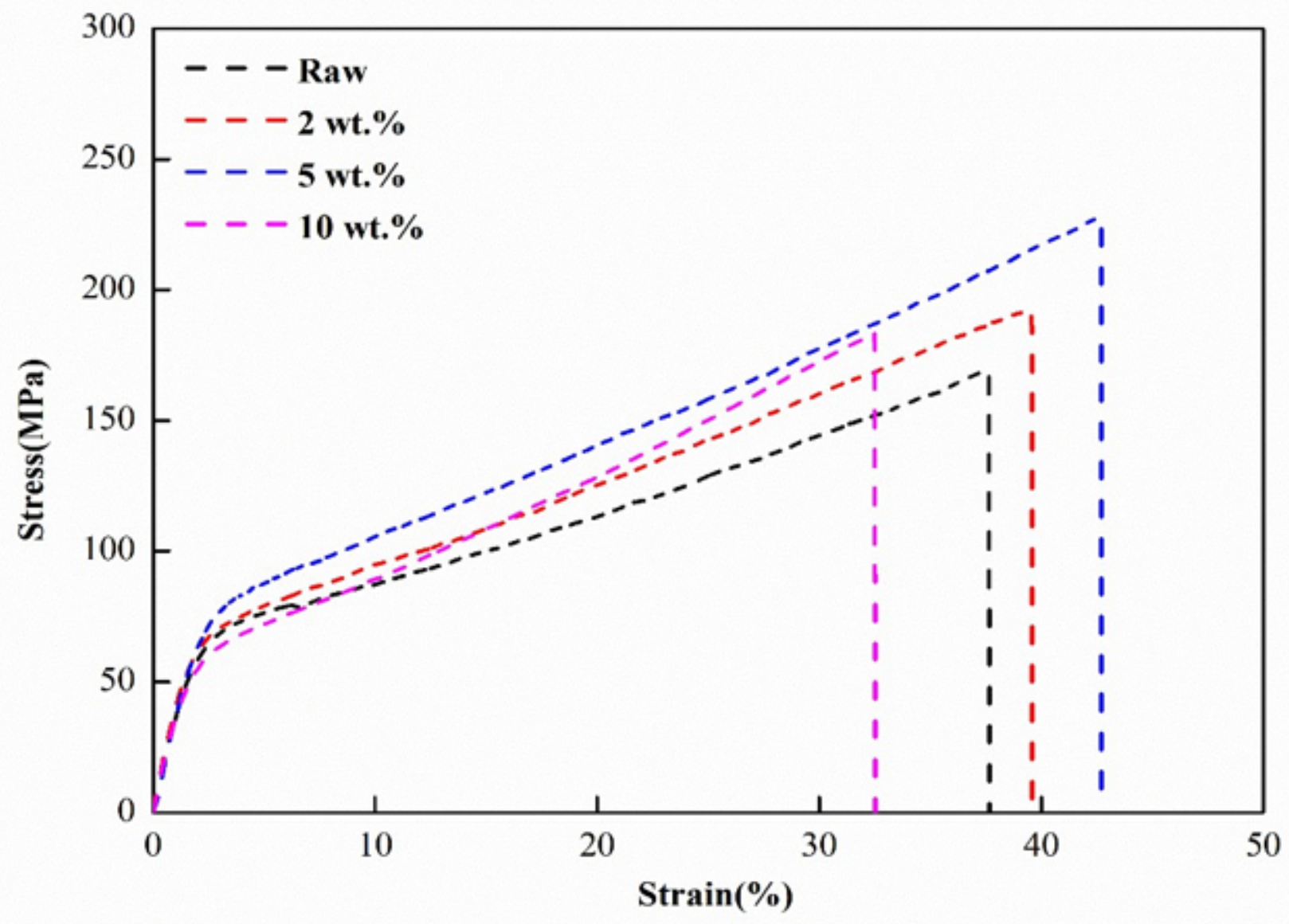

Figure 2

Tensile stress-strain curves of palm fibers: raw and alkali treatment for different conditions. 
(a)
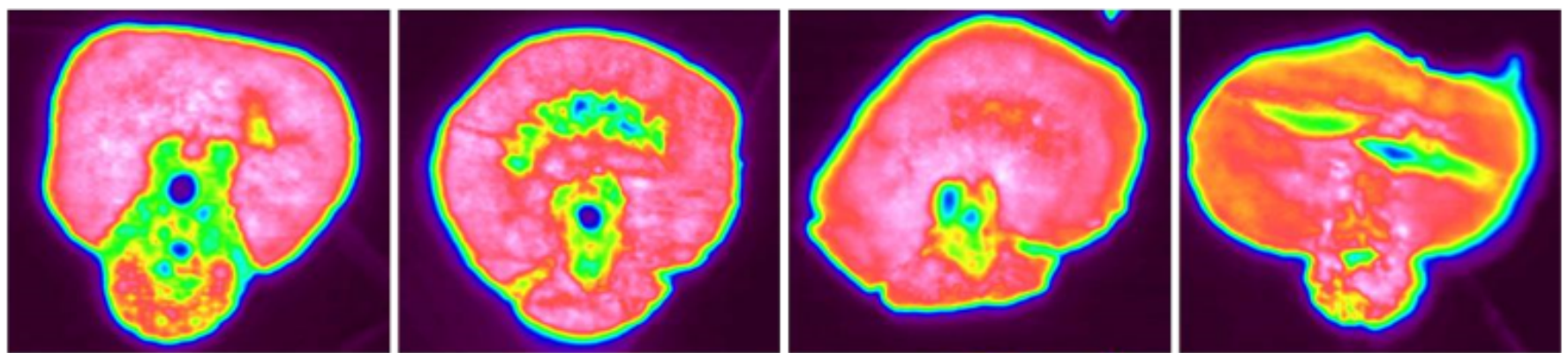

(b)
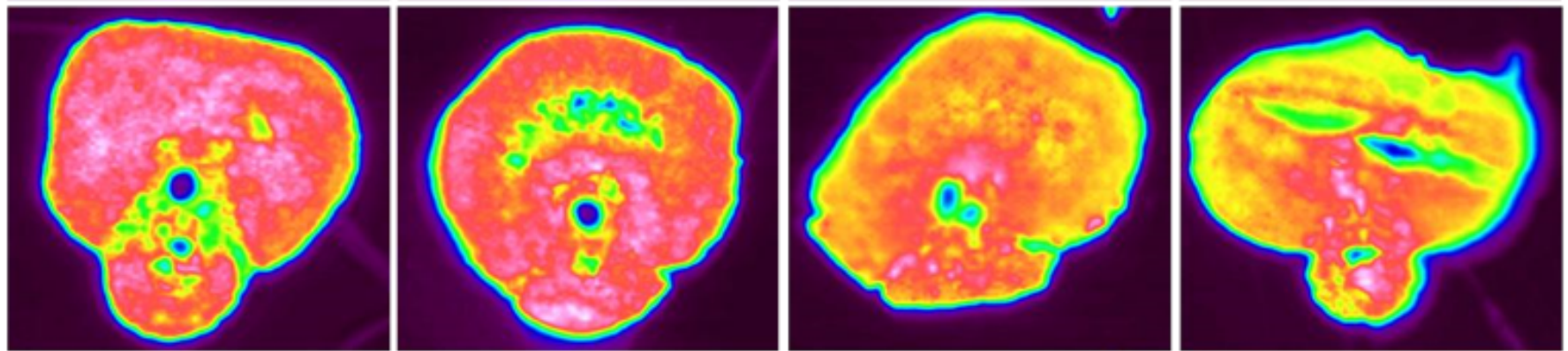

(c)

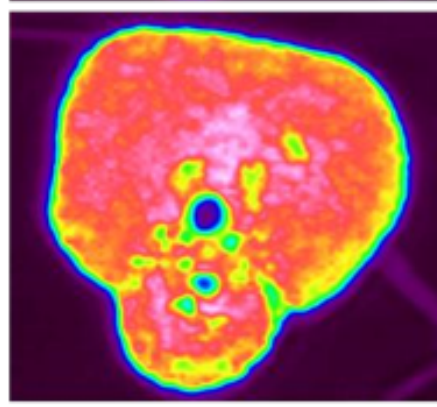

Raw

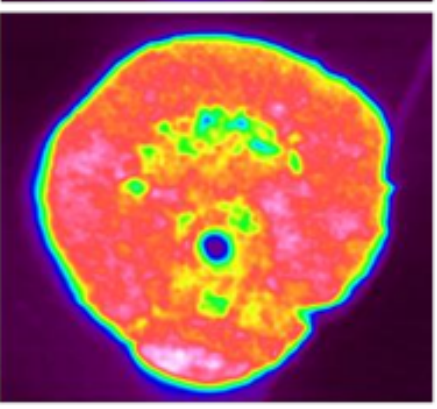

2 wt. \%

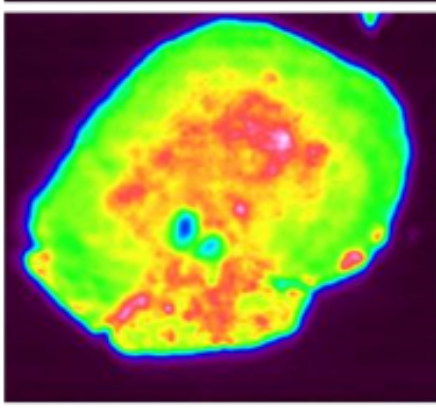

5 wt. $\%$

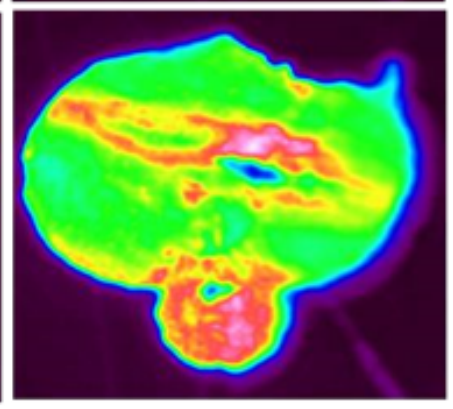

10 wt. $\%$

\section{Figure 3}

(a) Spectral image under the peak at $1240 \mathrm{~cm}^{-1}$, showing the relative concentration and distribution of cellulose. (b) Spectral image under the peak at $1508 \mathrm{~cm}^{-1}$, showing the relative concentration and distribution of lignin. (c) Spectral image under the peak at $1710 \mathrm{~cm}^{-1}$, showing the relative concentration and distribution of hemicelluloses. 


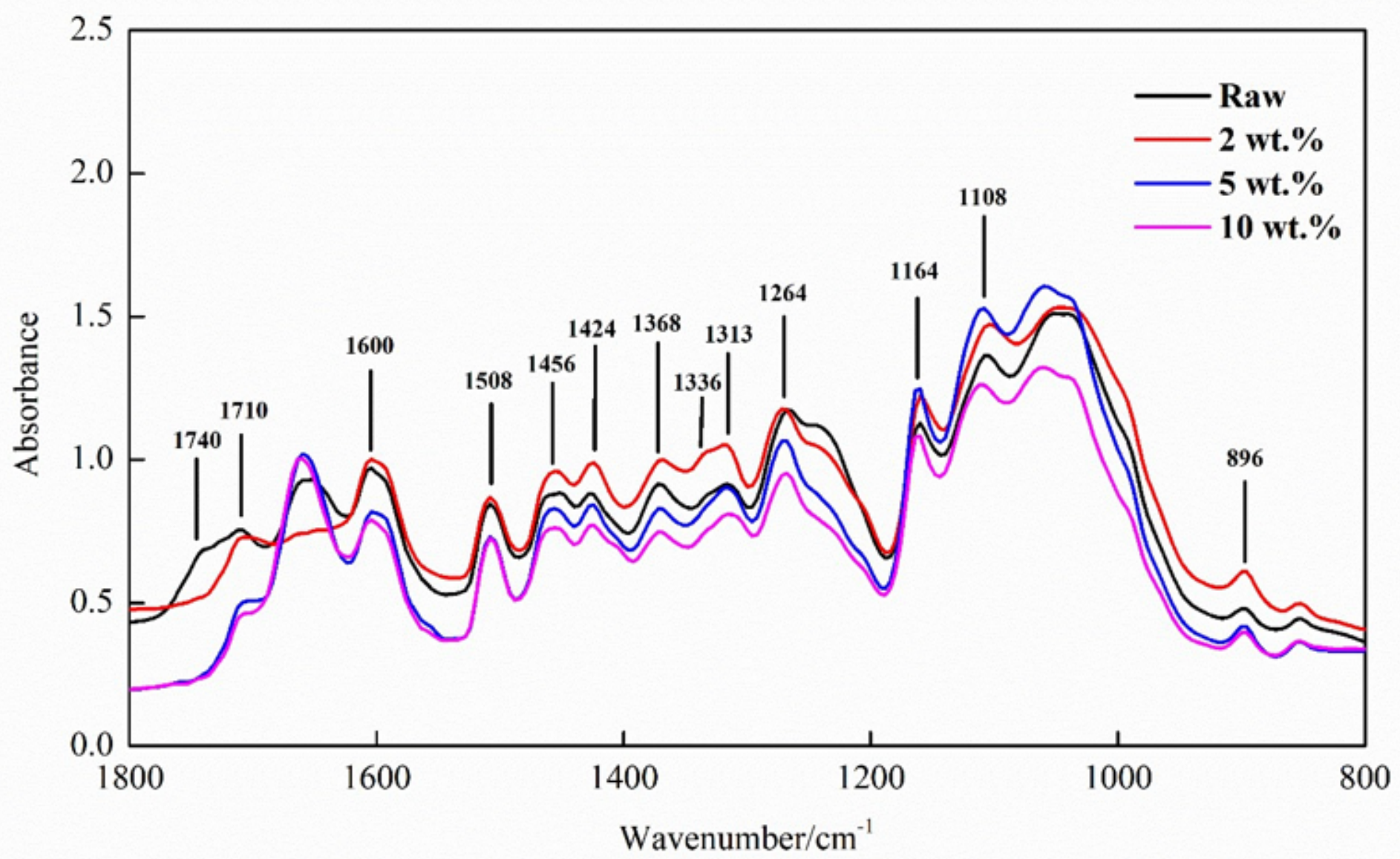

Figure 4

FT-IR spectra of the cell wall of fibers in the fingerprint region 


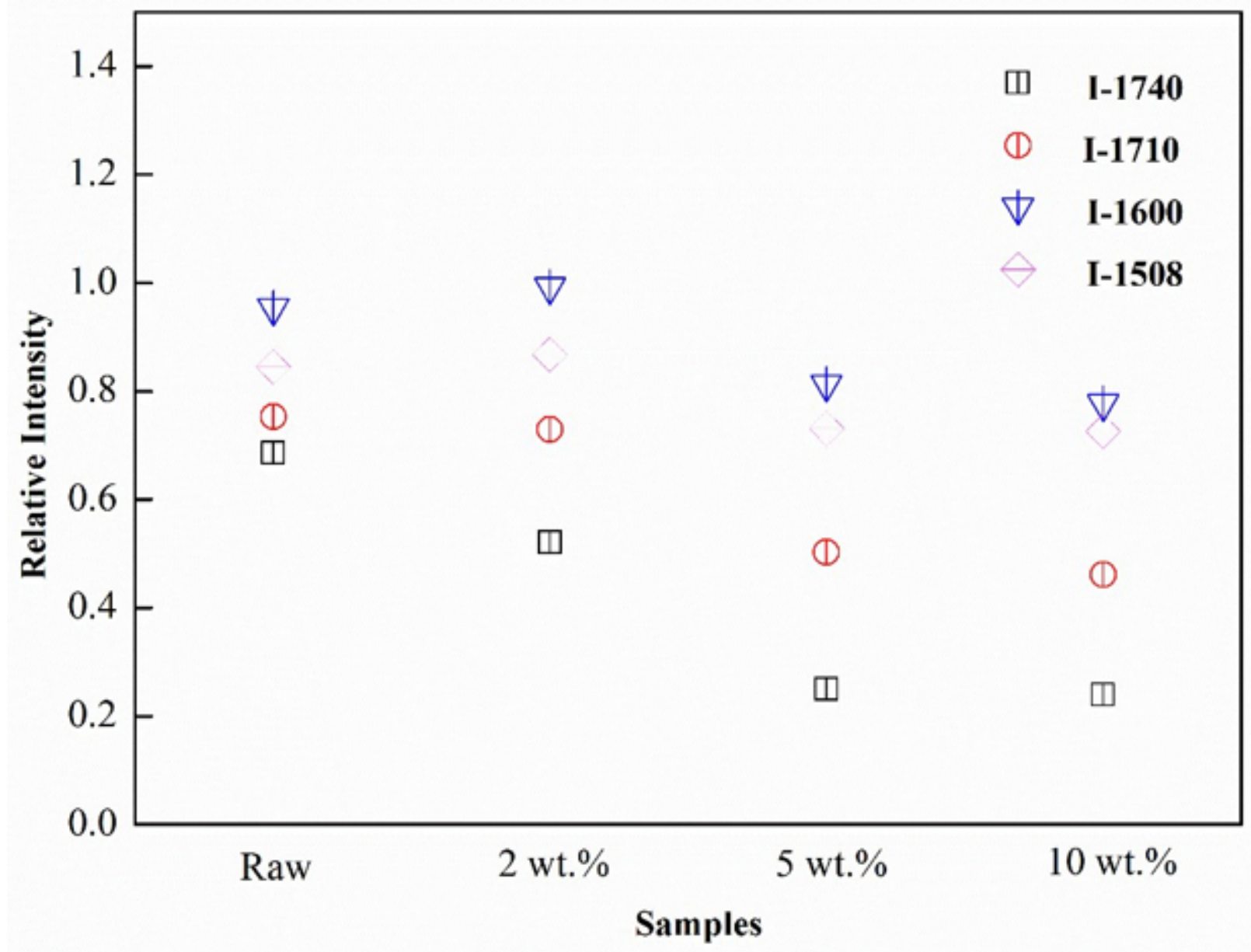

Figure 5

The relative intensities of the absorption peaks at 1740, 1710, 1600, and $1508 \mathrm{~cm}^{-1}$ in palm as a function of treatments 

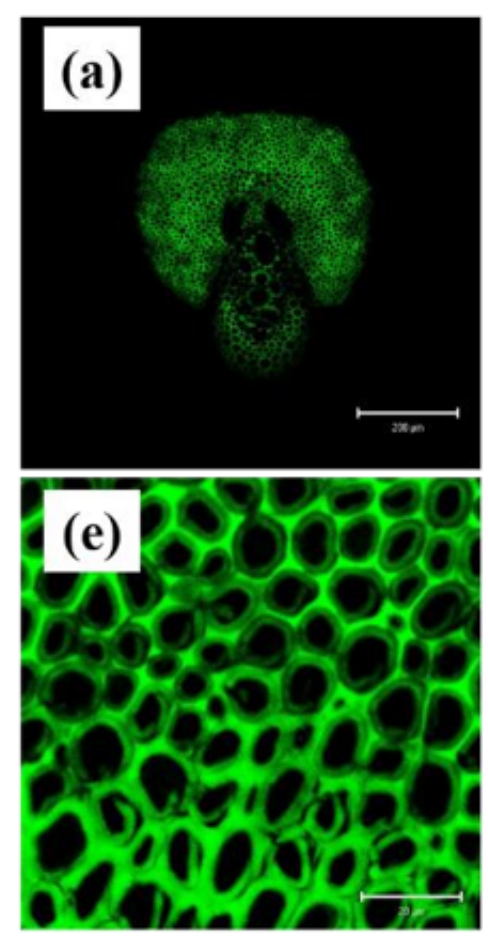

Raw
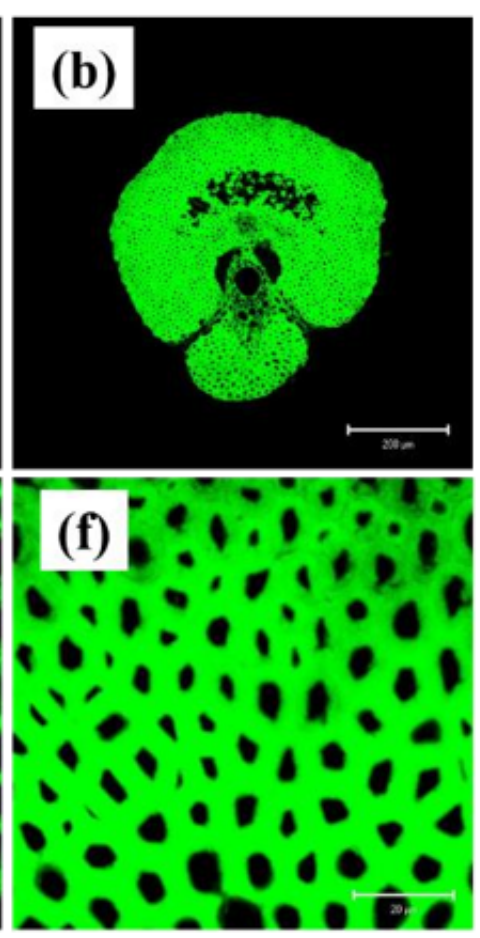

2 wt. $\%$
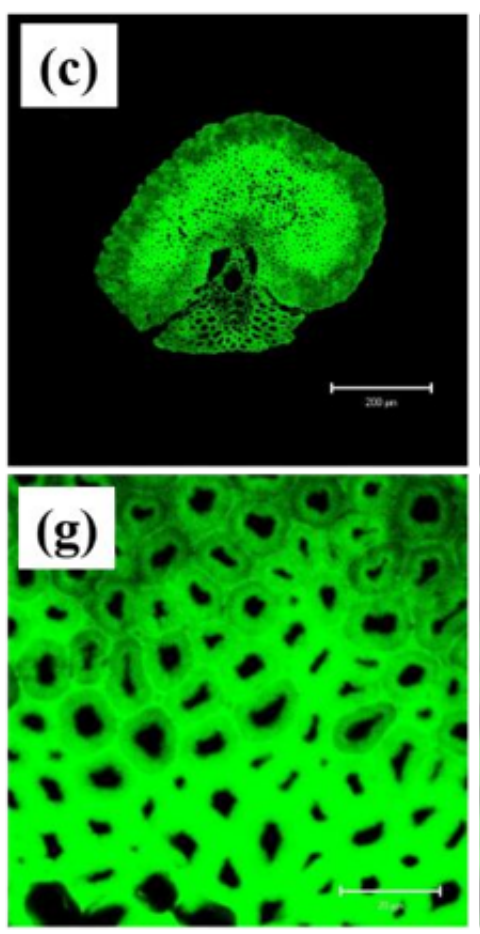

5 wt. $\%$
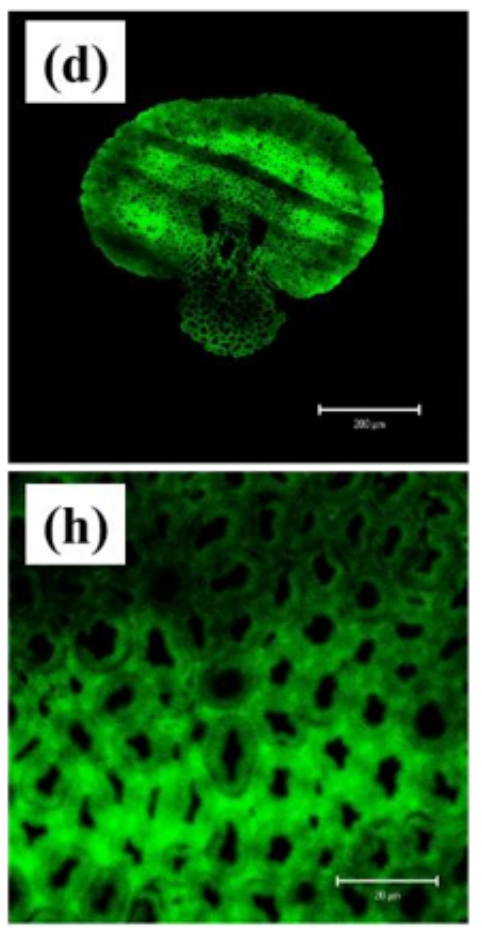

10 wt. $\%$

Figure 6

Fluorescence images of transverse section of raw, alkali-treated at $2 \mathrm{wt} . \%$, alkali-treated at $5 \mathrm{wt} . \%$, and alkali-treated at $10 \mathrm{wt} . \%$ palm cells. 